\title{
3 Slavery and Skin: The Native Americans Ocktscha Rinscha and Tuski Stannaki in the Holy Roman Empire, 1722-1734
}

\section{"Two Renowned and Wild Indian Princes"?}

In early January 1722, an unlikely group of four travelers arrived in Frankfurt am Main and made their way to the "Imperial Crown" guesthouse. ${ }^{1}$ The man in charge was English, styled a sea captain. The oldest of the group, he spoke no German and communicated through an interpreter later described as "a Jew in German clothing" or "an Englishman who speaks German."2 The two others - young men in their twenties - were the reason the group was traveling: "they were decorated everywhere on their bodies with hieroglyphic figures and characters [. . .] and one could view them for eight Kreutzer." 3 Marked from head to foot with extraordinary images of suns, moons, snakes, as well as other figures and complex patterns, they were also battle-scarred. No one had ever seen anyone like them in this part of Europe. ${ }^{4}$

1 Newspaper references to the travels of the "Princes" indicate that they arrived in Frankfurt from Mainz between January 6 (the Munich Mercurii Relation, oder wochentliche Ordinari Zeitungen von underschidlichen Orthen, January 31, 1722) and January 10 (January 20, 1722 edition of the Oprechte Haerlemsche Courant, reporting from Brussels). On their lodging, see Johann G. Batton and Ludwig Heinrich Euler, Oertliche Beschreibung der Stadt Frankfurt am Main, vol. 6 (Frankfurt: Verlag des Vereins für Geschichte und Alterthumskunde zu Frankfurt am Main, 1871), 73: "Reichskrone, ein Gasthaus, das aus mehreren zusammengekauften Häusern besteht, und hinten in die Schäfergasse eine Ausfuhr hat. Es hiess sonst die alte Krone, denn in der Chronik I. 432 wird von einer Bären- und Ochsen- Hatze gemeldet, die 1701 von einigen Engländern auf der Friedbergergasse in der alten Krone gehalten wurde. Der Name Reichskrone kömmt aber [. . . ] 1704 schon zum Vorschein.”

2 Sammlung von Natur- und Medicin- wie auch hierzu gehörigen Kunst- und Literatur-Geschichten so sich von 1717-26 in Schlesien und anderen Orten begeben [. . .] und als Versuch ans Licht gestellet [for 1722] 21 (1724): 311, and Acta Lipsiensium academica: oder, Leipziger Universitäts-Geschichte 1 (1723): 87.

3 Johann Adolph Stock, Kurtz gefaßte Franckfurther Chronik: In welcher das Denck-und Merckwürdigste, so sich vom Jahr 742. nach unsers Heylandes Geburt biß auf unsere Zeiten allhie zugetragen (Frankfurt: Stock und Schilling, 1745), 166: "Im Jahr 1722 den 12 Jan. waren allhier in der Reichskron zwey americanische Prinzen zu sehen, Sie sind an ihren Leibern durchaus mit hieroglyphischen Figuren und Charactern bemahlet gewesen, sie hatten Pechschwarze Haare und eine braune Haut, waren aber nicht gar groß von Person. Man konte sie vor acht Kreutzer zu sehen bekommen.”

4 We know very little about Native Americans in German-speaking Europe before 1750. I have documented two instances prior to the arrival of Ocktscha Rinscha and Tuski Stannaki: In 1708, the wealthy young Bostonian Jonathan Belcher visited Princess Sophia, Electress of Hanover and mother of the future King George I, at her court and presented her with a Native slave boy named "Io" as a gift. And in September 1720, an "Indian prince and princess" from Florida (whose names 
The two men were Native Americans: Ocktscha Rinscha and Tuski Stannaki, as they later signed their names. As captives of a Carolina slave trader, their elaborately decorated bodies had become profitable curiosities to which viewing access was sold. Ocktscha Rinscha, the older man, was Choctaw; Tuski Stannaki, the younger, likely Creek. They traveled with their owner, a "Considerable Indian trader" named John Pight, and were described as slaves in the many sources documenting their time in the Holy Roman Empire. Pight took the men from Charleston, South Carolina to England in 1719, then to France in the summer of 1720. Some time later, the group of four men must have entered the Holy Roman Empire, and by January 1722, they had reached Frankfurt am Main, on their way, they explained, to Vienna. After Vienna, they went north to Breslau and then, fatefully, to Dresden, capital of the Electorate of Saxony. Of the years they spent in Europe, they lived for a decade in the lands of Augustus the Strong, King of Poland and Elector of Saxony - first in Dresden, then in Warsaw. They were slaves when they entered Saxony, and it is not clear how - or if - they were ever considered free.
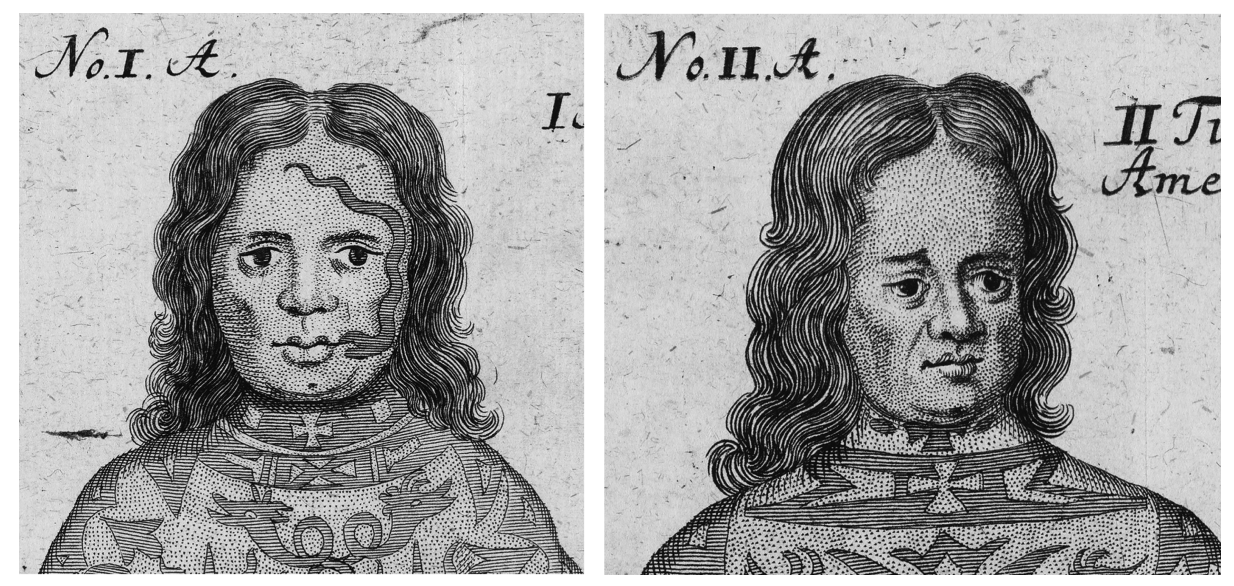

Fig. 3.1: Ocktscha Rinscha and Tuski Stannaki. Details from the Breslau Sammlung von Natur- und Medicin-[. . .] Geschichten, [1722]. Courtesy of Sächsische Landesbibiothek - Staats- und Universitätsbibliothek Dresden/ Deutsche Fotothek.

Ocktscha Rinscha and Tuski Stannaki were tough, adaptable, cross-cultural survivors, and their story demands to be told elsewhere in more detail. By establishing some essential facts about their route through Central Europe and their reception by Germans, however, we can both establish a foundation for the further study of these men in Native history and uncover new attitudes toward skin, slavery, and

are given as "Illa Cadego" and "Toche Hoga") arrived in Amsterdam. Later that same year, they were brought to the Hessian court in Kassel. 
race in Germany in the early eighteenth century. The lives of Ocktscha Rinscha and Tuski Stannaki help reveal how Germans understood these three pillars of the Atlantic world in terms of the "hieroglyphic figures and Indian characters" they bore on their skin (see Figs. 3.1, 3.4, 3.5)..$^{5}$

Ocktscha Rinscha and Tuski Stannaki crossed the Atlantic as captives of John Pight, a notorious enslaver of Native people in the American Southeast (see Fig. 3.2). He was born around 1670 in England and made his way to the Carolina colony, where by 1694 he owned a small plantation in Goose Creek outside of Charleston. Known for their violence and duplicity, the "Goose Creek Men” included many settlers from Barbados, England's first slave society. In Carolina, these men kept enslaved Africans, but they also "turned to what they knew and started enslaving Indians, or rather encourag-

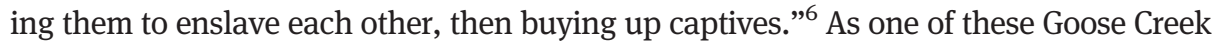
Men, Pight ranged west as far as the lands of the Creek and Cherokee, exchanging guns, powder, and other manufactures for furs, hides, and enslaved Native people, and he rose to become an important Indian trader in the years after $1700{ }^{7}$ He spoke at least one Native language, perhaps the Mobilian trade language (also called the Chickasaw-Choctaw trade language). Leading defensive and raiding parties of Africans, Native people, and Europeans, Pight's greed and lawlessness helped provoke a conflagration called the Yamasee War in 1715 - a Native rebellion so extensive that Charleston itself was at risk of destruction. ${ }^{8}$ Ocktscha Rinscha and Tuski Stannaki may have been captured during this wave of violence. When the Yamasee War ended in 1716, Pight was politically outmaneuvered and essentially banished from Carolina. His days as an Indian trader had come to an end.

But he still possessed a number of Indian captives, among them Ocktscha Rinscha and Tuski Stannaki. Aged about 27 and 22 years old, the two young men were from somewhere to the west - between "the English province of Carolina and the

5 To an extraordinary degree, this chapter is built upon the generosity of colleagues, especially Mark Häberlein (who alerted me to letters re. the two Native men in the database of the Franckesche Stiftungen in Halle), Rebekka v. Mallinckrodt (who shared with me her research in the Dresden Hofbücher), and above all John Jeremiah Sullivan, who has been so generous with his notes and other materials, which all reflect an enormous amount of careful research.

6 Their story has been examined from a Choctaw perspective by the Iti Fabvssa staff writers of the Choctaw Nation Historic Preservation Department, "Story of a Choctaw POW Comes to Light after 300 Years,” BISKINIK (Jan. 2014): 12, and was first mapped out (to 1725) by John Jeremiah Sullivan, “The Princes: A Reconstruction,” The Paris Review 200 (Spring 2012): 35-88.

7 In 1706, the Anglican missionary Francis Le Jau described Pight (here "Pike”) as a "Considerable Indian trader" with a good knowledge of Native languages. See The Carolina Chronicle of Dr. Francis Le Jau, 1706-1717, ed. Frank J. Klingberg (Berkeley: University of California Press, 1956), 19. See also William L. Ramsey, “A Coat for 'Indian Cuffy': Mapping the Boundary between Freedom and Slavery in Colonial South Carolina,” The South Carolina Historical Magazine 103, no. 1 (2002): 48-66, esp. 51-53.

8 John J. Navin, The Grim Years: Settling South Carolina, 1670-1720 (Columbia: University of South Carolina Press, 2019). 
Mississippi" according to one account. ${ }^{9}$ Their names offer some evidence of their origins: Ocktscha Rinscha, the older, was probably Choctaw; the younger Tuski Stannaki may have been Muscogee Creek. When they arrived in Breslau in August 1722, their full names were given as "Oak Charinga Tiggvvavv Tubbee Tocholuche inca Navvcheys" and "Tuskee Stannagee Whothlee Powvovv Micko Istovvlavvleys" by their captor. ${ }^{10}$ In a London account, they were described thus: "the first is Son of the Emperor of the Nawcheys, his name is Oakecharinga Tiggwawtubby Tocholochy Ynca; the other, who is Son of the King of the Istowlawleys, they call Tuskestannagee Whosly Powon Micco."11 The name of the elder man, billed as "son of the Emperor of the Natchez" actually offers strong evidence of Choctaw origin. Working from the English newspaper rendering, a Native language expert has observed that "most of the words in the first name definitely seem to be Choctaw. Oakecharinga = Okchanilncha $=$ 'Brought to Life'. Tigwatubby $=$ Tikbatibby $=$ 'Kills First' (a classic Choctaw war title). Tocholochy = Tusholach = 'will translate'. Ynca appears to be totally fraudulent." In the name given for the younger man, "Tuskestannagee clearly seems to be the Muscogee word 'Tvstvnvke', which means 'Warrior'. Also, 'Micco' means 'Chief' in Muscogee." ${ }^{\prime 2}$ Scholars agree that some parts of each name were likely invented by their captor, Pight.

After the men had become fluent in German, they signed their own Native names as "Ocktscha Rinscha” and "Tuski Stannaki” on a 1725 letter requesting permission to be baptized. ${ }^{13}$ These names correspond to the Choctaw and Muscogee Creek elements in their respective names as given earlier by Pight in London and Breslau. Given the discovery in 2018 of this document featuring their distinct signatures (see Fig. 3.3), I use “Ocktscha Rinscha” and "Tuski Stannaki" as the most accurate versions of the Native names of these men.

9 Der Leipziger Spectateur: welcher die heutige Welt, der Gelehrten und Ungelehrten, [. . . ] Leben und Thaten, Auch wohl Schrifften, beleuchtet und ihnen die Wahrheit saget 3 (1723): 145-152, here 146.

10 Sammlung von Natur- und Medicin-[. . .] Geschichten [for 1725] 34 (1727): 472, quoting the entry in English: "Breslau August the 29. 1722."

11 The Weekly Journal or Saturday's Post, December 26, 1719, 334: “On Monday Night last a Comedy called, The Taming of the Shrew, or Sawney the Scot, was acted at the new Theatre in Little Lincoln's-Inn-Fields: The House was very full; there were present two American Princes, who are lately arrived from the Continent lying on the Coast of the River Missisippi, and for whose Entertainment that Play was intended. They seemed wonderfully delighted with the Performance, and the fine Company. Their Highnesses Dress was, indeed, something particular, and made but an indifferent Appearance, though it was pretty well too; but their Names being none of the least remarkable, we shall give them for the Entertainment of our Female Readers; the first is Son of the Emperor of the Nawcheys, his name is Oakecharinga Tiggwawtubby Tocholochy Ynca; the other, who is Son of the King [sic] of the Istowlawleys, they call Tuskestannagee Whosly Powon Micco.”

12 Lars F. Krutak, Tattoo Traditions of Native North America: Ancient and Contemporary Expressions of Identity (Arnhem: LM Publishers, 2014), 199.

13 Hauptstaatsarchiv Dresden, 10025 Geheimes Konsilium, Loc. 4692/07, fol. 3r. 


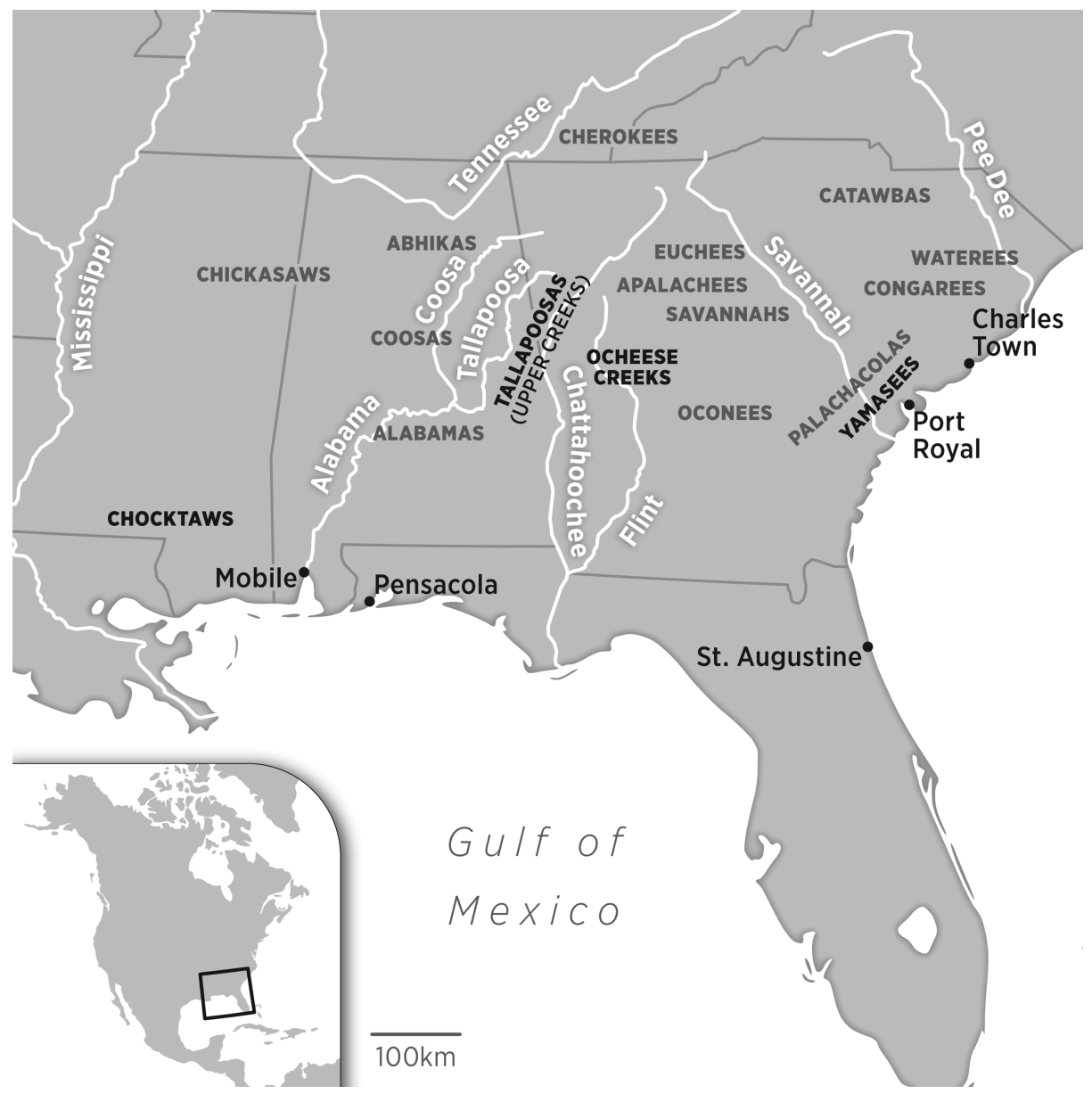

Fig. 3.2: The Southeast on the eve of the Yamasee War, 1715, showing the possible origins of Ocktscha Rinscha (Choctaw) and Tuski Stannaki (Creek). Map by Daniel P. Huffman.

All reports agree that both men were inscribed from head to foot in an extraordinary array of permanent markings. Sometime in 1719, Pight - who had spent his life dealing in commodified human bodies - decided to exploit these dermal marks by taking the Native Americans to England for display. They arrived in London in August 1719, where Pight charged all manner of people all manner of prices to see them and the intricate patterns and images on their skin, presenting them as Native "princes" or "kings." Announced by a newspaper advertisement or handbill, Pight would set up shop at an inn or coffeehouse and charge visitors a few pence to see the men. London's theaters, he discovered, would pay for the men to attend a play, counting on a bigger audience once it was known that the "Princes" would be in attendance. On 


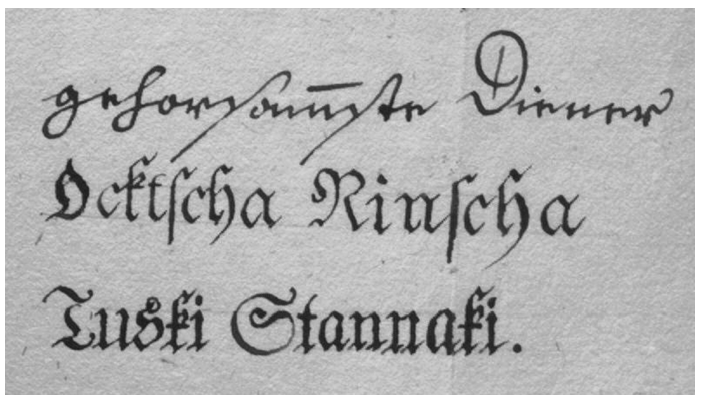

Fig. 3.3: "Most obedient servants Ocktscha Rinscha; Tuski Stannaki." Signatures of the two men on their request to be baptized as Lutherans in Dresden, 1725. Sächsisches Staatsarchiv, Hauptstaatsarchiv Dresden, 10025 Geheimes Konsilium, Loc. 4692/07, fol. 13r.

one occasion, they were made to perform a "war dance."14 By the spring of 1720 , however, London had grown tired of this sensation - and of Pight, whose greed seems to have been evident to all observers. ${ }^{15}$ Pight and his captives departed for Paris, arriving there in late May or early June $1720 .{ }^{16}$ Their visit coincided with the collapse of the Mississippi Bubble and was not a success. The trail of Ocktscha Rinscha, Tuski Stannaki, and John Pight disappears between the summer of 1720 and January 1722, when they arrived in Frankfurt. ${ }^{17}$ As we will see, their time in the Holy Roman Empire would transform the two Native men.

\section{Bought and Sold in the Holy Roman Empire}

The travels of Ocktscha Rinscha and Tuski Stannaki in the Holy Roman Empire have not yet been entirely reconstructed (see Fig. 3.6). They must have entered the Empire in late

14 Emmett L. Avery, ed., The London Stage: 1660-1800: A Calendar of Plays, Entertainments \& Afterpieces together with Casts, Box-Receipts and Contemporary Comment [. . .] Vol. 2, 1700-1729 (Carbondale: Southern Illinois University Press, 1960), 574.

15 In the April 4, 1720 issue of his periodical The Anti-Theatre, Richard Steele complained of the "stronger notions of fingering money" of Pight, described here as the "interpreter" for the two Native men. This 1720 periodical was reprinted in Richard Steele, Colley Cibber, John Dennis, John Nichols, and John Falstaffe [the last two being pseudonyms of Steele], The Theatre: to which are added, the Anti-Theatre; the Character of Sir John Edgar; Steele's Case with the Lord Chamberlain; the Crisis of Property, with the Sequel, Two Pasquins, \&c. \&c. (London: Printed by and for the editor and sold by G.G.J. and J. Robinson [. . .] J. Walter [. . .] and C. Dilly, 1791), here 294-296.

16 Further research is needed to reconstruct the visit of the men to Paris in the summer of 1720.

17 Where were they? John Jeremiah Sullivan suspects they may have simply returned to England and to Pight's daughter's home in Somerset (John Jeremiah Sullivan, Personal communication with the author, January 2019). See also Sullivan, "The Princes: A Reconstruction.” 
1721, given that they arrived in Frankfurt in early January 1722. According to Dutch and English newspaper reports, they intended to travel south and east from Frankfurt to Vienna by way of Mannheim and Augsburg. ${ }^{18}$ Considering this route, they may have come to Frankfurt from the north, but no records of the "American Princes" in Hamburg, Bremen, Cologne, Berlin, Hannover, or Kassel have surfaced. It seems unlikely that they came by way of the Netherlands: Dutch newspapers, especially the Oprechte Haerlemsche Courant, described their stay in London, reported in detail on their time in France (in July 1720), and noted their arrival in Frankfurt (in January 1722). If they had been seen in the Low Countries during this time, it seems very likely that a Dutch newspaper would have reported it - but no notice of them in the Netherlands has been found in any Dutch publication. ${ }^{19}$ It is not possible to confirm that they actually stopped in Mannheim or Augsburg after leaving Frankfurt around January 20, 1722, but they definitely reached Vienna in May of that year.

Why Vienna? By the time Ocktscha Rinscha and Tuski Stannaki arrived in Germany, they had been traveling with Pight as his captives for two and half years. As John Jeremiah Sullivan has argued, Pight may have realized he had reached end of the line with this "show." In German sources, we hear for the first time that the two men were now for sale as slaves. ${ }^{20}$ Pight (whose name is given as "Pecht" in German sources) seemed to hope to sell them to a ruler in the Holy Roman Empire. With this plan in mind, he may have headed first to the Habsburg imperial court as the most prestigious in the Empire.

When Pight arrived in Vienna, he ran an advertisement in Vienna's only newspaper, the Wienerisches Diarium, on May 20, 1722:

\begin{abstract}
Notice is hereby given, that the two renowned and wild Indian princes, Sauase Oke Charinga and Tusskee Stannagee from the new world, America, have arrived here in Vienna. The decorations on their bodies have made them a great wonder everywhere: their bodies are covered with hieroglyphic figures and Indian characters so well-drawn that nothing can exceed them. These [figures] distinguish their families and represent the victories their ancestors attained in battle, so [many] that their entire bodies seem to be covered with clothing. Such a rare sight, so worth seeing, has drawn many learned and thoughtful people to satisfy their curiosity. They have been viewed and admired with extraordinary pleasure at many French, English, and German courts, universities and other places of learning. To this end they now have arrived here as well, and are lodging at the Rooster-Bite [Haanen-Beiß] inn, on the first floor of the courtyard. N.B. If any cavalier or lady would like to view these Indian princes in their private residence, they will not fail to come if so informed. ${ }^{21}$
\end{abstract}

18 See the January 20, 1722 edition of the Oprechte Haerlemsche Courant as well as the Whitehall Evening Post of January 13, 1722.

19 Furthermore, although Pight boasted in his advertising that they had visited "English, French, and German courts" and universities, he did not mention the Low Countries.

20 Kurtzgefastes sächsisches Kern-Chronicon, worinnen [. . .] etliche hundert merckwürdige alte und neue Glück- und Unglücks-Fälle, Festivitäten, Geburthen, Vermählungen und Absterben [. . . ] bis hierher zugetragen [. . . ] 3 (1722/23): 38.

21 Wienerisches Diarium, May 20, 1722: "Es dient zur Nachricht, daß die Zwey berühmt-wilde Indianische Printzen, Sauase Oke Charinga und Tuskee Stannagee, aus der neuen Welt America alhier 
This text, which Pight also used on handbills in Breslau and Dresden, presents AngloAmerican ideas about Native and enslaved people to a German audience. Since the visit of the "Four Indian Kings" to London in 1710, all further Native visitors to England were presented as kings or princes of some sort, and Pight followed suit, claiming - as discussed below - that the men's tattoos were proof of their royal status. ${ }^{22}$ Ocktscha Rinscha and Tuski Stannaki were of course in no way "wild," as the report about them published later in Breslau emphasizes. In fact, Pight presented their marked skin as the product of a complex culture. He had spent the previous thirty years of his life kidnapping and trading with Native Americans in the Southeast, and as a speaker of at least one Native language, he likely knew something about the cultures of the people he traded with and preyed upon. His description of Ocktscha Rinscha and Tuski Stannaki emphasizes the intelligibility of the "hieroglyphic figures and Indian characters" on their bodies: the marks were highly meaningful (to those who could read them), representing their lineage and family history. Significantly, as we will see below, observers in Breslau and Leipzig disputed the legibility of the marks.

Sometime in the summer of 1722, the "Princes" left Vienna; Pight's daily exploitation of the men may have undermined his plan to sell them. As a Leipzig journal later noted, making the men available for public viewing made them common, and so less valuable to a royal court interested in tokens of worldly exclusivity. ${ }^{23}$ Our next available sources show Pight and his captives arriving in Breslau in late August 1722 - it is not known whether they stopped for any length of time along the way. ${ }^{24}$

When the men arrived in Breslau, Pight gave out a printed handbill with the same text as the Vienna advertisement and began displaying Ocktscha Rinscha and Tuski Stannaki immediately "in a tavern, and then in the fencing school (as it is called) [. . .] for a Sieben-Zehner, then for just a Sieben-Creuzer [the equivalent of a few English pence].” A few days after their arrival, they were summoned to the town hall by the Breslau authorities to "present themselves." 25 The roughly two months that Ocktscha Rinscha and Tuski Stannaki spent in Breslau resulted in an extraordinary cultural and representational output: "Certain learned men curious about nature in Breslau" published both the most detailed written description of the Native men known to us (seven pages) and two detailed prints of their tattooed bodies (Figs. 3.4, 3.5). ${ }^{26}$ The Breslau material was published in the Sammlung von Natur-

in Wien angelangt, welche wegen derer auf ihren Leibern befindlichen Zierraten / überall höchlich bewundert worden [. . . ]”.

22 Alden T. Vaughn, Transatlantic Encounters: American Indians in Britain, 1500-1776 (New York: Cambridge University Press, 2006), 133.

23 Leipziger Spectateur 3 (1723): 150.

24 The Moravian city of Brno/Brünn would be a logical stopping point.

25 Sammlung von Natur- und Medicin-[. . .] Geschichten [for 1722] 21 (1724): 311.

26 The full article is in Sammlung von Natur- und Medicin-[. . .] Geschichten [for 1722] 21 (1724): 310-317. 
und Medicin-, wie auch hierzu gehorigen Kunst- und Literatur-Geschichten so sich in Schlesien und andern Landern begeben [. . .] (Collection of Natural, Medical and Related Artistic and Literary Relations as Have Occurred in Silesia and other Lands), a popular-academic journal, ${ }^{27}$ and reveals the curiosity evoked by the men as well as their objectification and commodification.

The Breslau authors narrate firsthand a visit to the inn where the men could be viewed. After carefully inspecting the exposed bodies of the men, the authors sought to converse with them. This was not possible, however: The German-speaking interpreter either answered the questions himself or relayed them to Pight in English. The observers were told that the Native men never conversed directly with any other people. When they asked whether "their master (maitre) could talk with them instead" and relay their questions, they were informed that "they will not speak a word in front of other people; only in private could their master (maitre) talk with them.”28 The authors were nevertheless able to glean some details about Ocktscha Rinscha and Tuski Stannaki from the interpreter, however accurate they might be: They were told that to pass the time during their travels, the men had learned how to sketch (cityscapes among other subjects), and that they were beginning to understand German. ${ }^{29}$

According to the Breslau article, the detailed images of the two men engraved and printed with the article in the Collection of Natural, Medical and Related Artistic and Literary Relations were "drawn from life." These prints have recently been referenced and reproduced by several scholars, but the comments on the images provided in the accompanying text and in other sources have not been taken into account. ${ }^{30}$ In addition to the serpent tattoo, Ocktscha Rinscha's face featured "a few other smaller signs, but the artist did not attend to them in the drawing." 31 Furthermore, the Breslau authors explain that "the feet were covered by stockings and otherwise fine, but in our illustrations the artist has made them a little too heavy." The hair of both men was

27 The "certain learned men curious about nature" who wrote and edited the journal included Johann Kanold, Johann Georg Brunschwitz, Johann Christian Kundman, and A. E. Büchner. They are also referenced as "certain Breslau physicians" on the title page of the journal.

28 The French word "maître" is used in the Breslau German text: Sammlung von Natur- und Medicin-[. . .] Geschichten [for 1722] 21 (1724): 314.

29 Sammlung von Natur- und Medicin-[. . .] Geschichten [for 1722] 21 (1724): 314.

30 Lars Krutak has placed the markings in the context of Woodlands warrior tattooing as "meaningful conduits through which supernatural power and esoteric knowledge flowed." See Krutak, Tattoo Traditions of Native North America, 198-200, and “Tattoos, Totem Marks, and War Clubs," in Drawing with Great Needles: Ancient Tattoo Traditions of North America, ed. Aaron Deter-Wolf and Carol Diaz-Granados (Austin: University of Texas Press, 2014), 95-130. Christian F. Feest, "Das Unverständliche, das Fremde und das Übernatürliche: Schlangen in religiöser Vorstellung und Praxis im Indigenen," in Schlangenritual: Der Transfer der Wissensformen vom Tsu'ti'kive der Hopi bis zu Aby Warburgs Kreuzlinger Vortrag, ed. Cora Bender, Thomas Hensel, and Erhard Schüttpelz (Berlin: Akademie Verlag, 2007), 119-151, discusses the snake imagery borne by Ocktscha Rinscha.

31 Sammlung von Natur- und Medicin-[. . .] Geschichten [for 1722] 21 (1724): 314. The Leipzig Spectateur 3 (1723): 148 mentions a moon on the right side of Ocktscha Rinscha's face. 


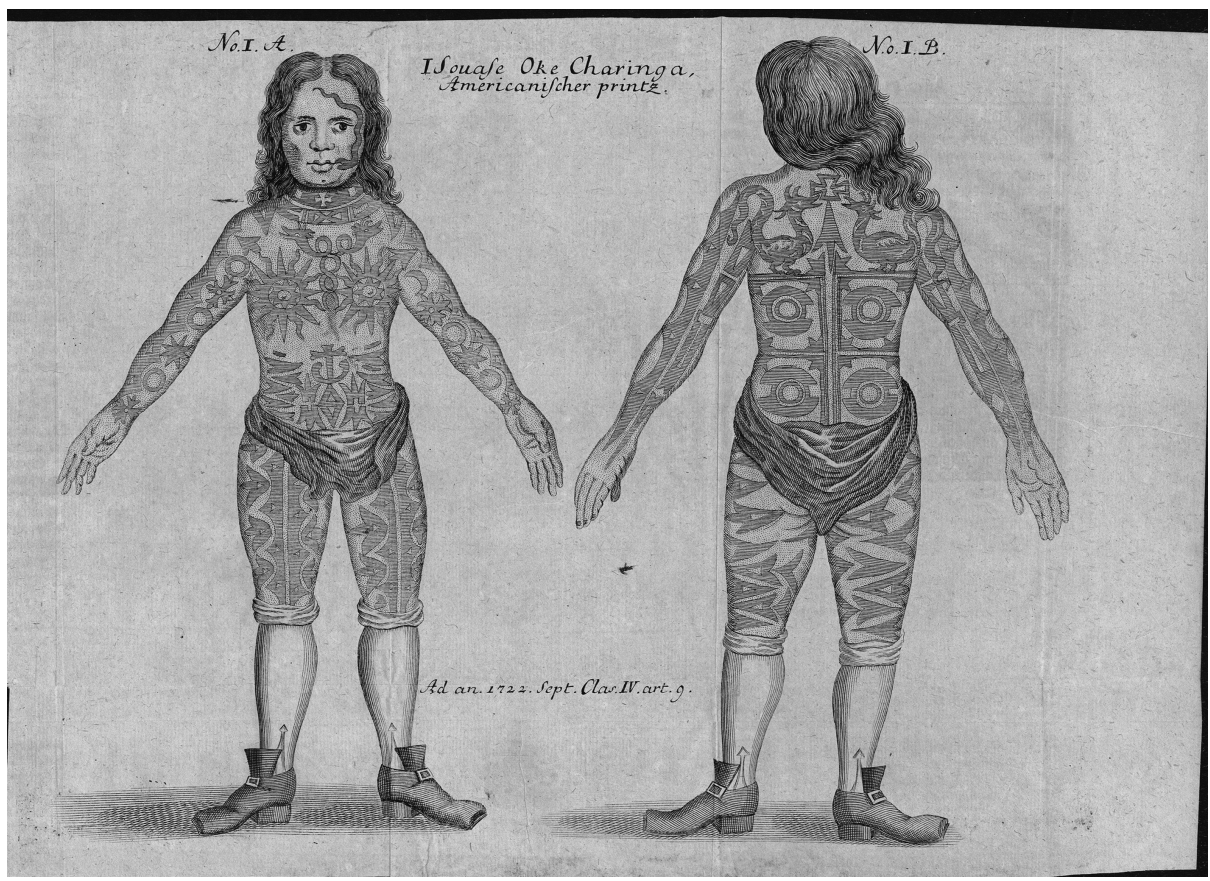

Fig. 3.4: "Souase Oke Charinga, Americanischer printz," from the Breslau Sammlung von Naturund Medicin-[. . .] Geschichten, [1722]. Courtesy of Sächsische Landesbibiothek - Staats- und Universitätsbibliothek Dresden/ Deutsche Fotothek.

apparently also longer and straighter than depicted, hanging down their backs, but "the artist [... .] drew it wavier and shorter, [and] so erred a bit." Other sources also mention noticeable battle scars on the men that are not visible in the Breslau prints. ${ }^{32}$

It is not clear why Pight chose to travel to Breslau, but while in the Silesian city he may have learned more about the lavish Saxon court to the west, in Dresden. In November of 1722, Pight and the two "American Princes" rode from Breslau to Dresden, passing through the village of Zittau on November $14 .{ }^{33}$ The official diary of the Dresden court recorded the arrival of the men on Friday, December 4: "An English ship captain arrived here with two American Princes, which he received as prisoners. They are called [blank lines for their names] and are marked on their entire bodies with many characters and images. ${ }^{34}$ The men lodged first at the Red Stag (Roter

32 On the scars, see Acta Lipsiensium academica 1 (1723): 86 as well as the Kurtzgefastes sächsisches Kern-Chronicon 3 (1722/23): 36.

33 On Zittau, see Sullivan, "The Princes: A Reconstruction," 39.

34 Hauptstaatsarchiv Dresden, 10006 Oberhofmarschallamt, O 04, Nr. 103: "Kam ein Engl. Schiffs Capitain mit zwey Americanischen Prinzen, so er allda gefangen bekommen alhier an, diese heißen [blank lines for names] und sind an ihren ganzen leibern mit viele Characteurs und Figuren 


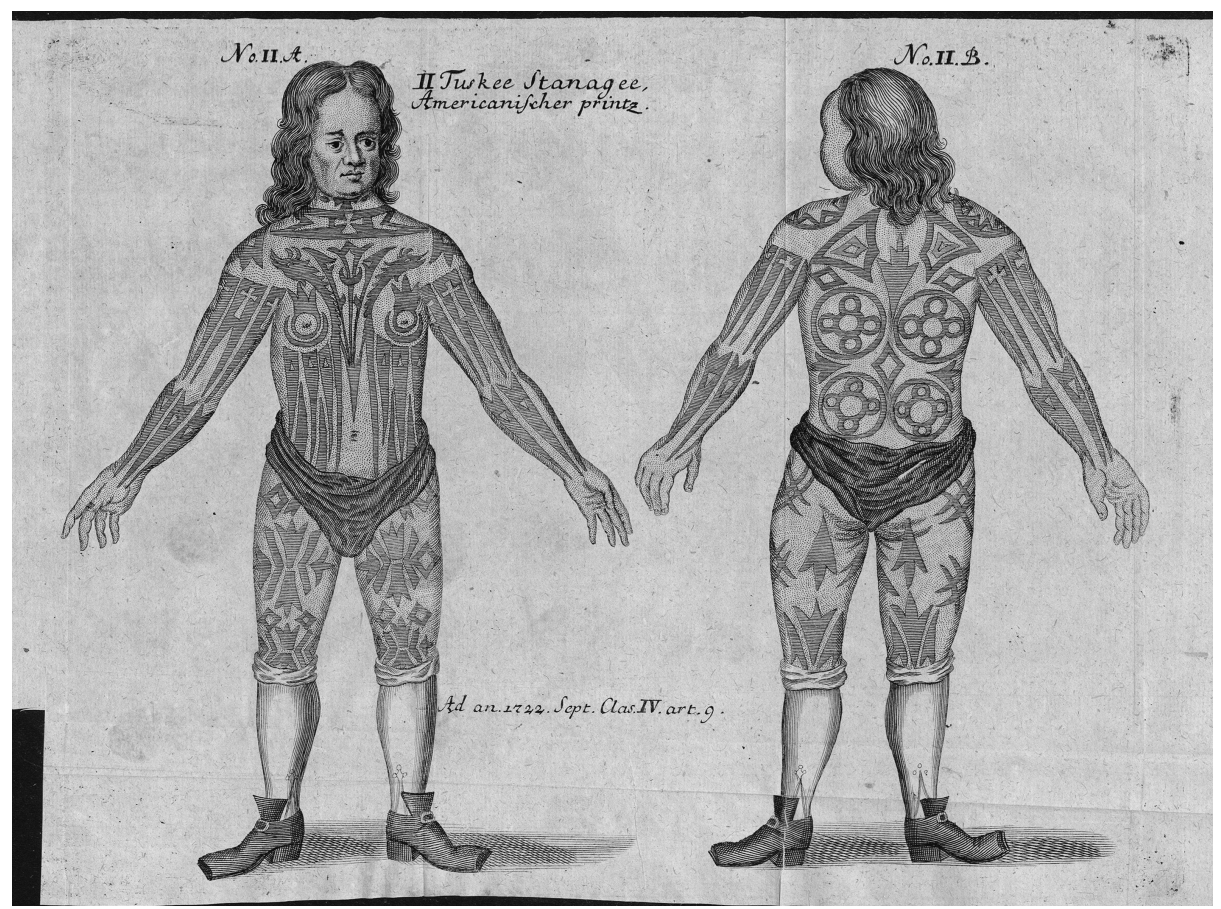

Fig. 3.5: "Tuskee Stanagee, Americanischer printz," from the Breslau Sammlung von Natur- und Medicin-[. . . Geschichten, [1722]. Courtesy of Sächsische Landesbibiothek - Staats- und Universitätsbibliothek Dresden/ Deutsche Fotothek.

Hirsch), then moved to the Golden Crown (Goldene Krone) inn. They were quickly received at the highest level of the Polish-Saxon court: on Monday, December 7 they were "magnificently hosted" by August Christoph Graf von Wackerbarth, Dresden's governor and a minister of state. ${ }^{35}$ On December 16, Pight brought Ocktscha Rinscha and Tuski Stannaki to an audience with the Saxon Electoral prince and princess at Taschenberg Palace. ${ }^{36}$ A Leipzig report dated December 20 claims that the Dresden court painter Louis de Silvestre had completed portraits of the men to send to Augustus II, King of Poland and Elector of Saxony, at his court in Warsaw, and that

gezeichnet.” The recorder of the court diary could apparently not immediately grasp Ocktscha Rinscha and Tuski Stannaki's names, so he left two blank lines in his note.

35 Hauptstaatsarchiv Dresden, 10006 Oberhofmarschallamt, O 04, Nr. 103.

36 Hauptstaatsarchiv Dresden, 10006 Oberhofmarschallamt, O 04, Nr. 103: "haben Ihro königl. Hoheit der Prinz und Prinzeßin die 2. Americanis. Printzen gesehen in der Pallais.” There are no further references to the Native men in the Hofdiarien for 1723, and the Hofdiarien for the years 1724-1733 are lost. 
these paintings would advance the "intentions of Herr Capitain Pecht [i.e., Pight] to sell these rare foreigners for a sum of money." 37

In January 1723, Pight took the men to Leipzig for the New Year's trade fair, lodging at the Three Roses (Drei Rosen) inn in Peterstrasse. ${ }^{38}$ The appearance of the "Princes" in this vibrant center of trade, publishing, and education prompted another wave of publications about them. ${ }^{39}$ The Leipzig Spectateur framed them as "wild, heathen Americans" who nevertheless "seem to possess great dignity and honesty" and "know nothing of falsehood and lies." The Native men were a moral rebuke to both their greedy guide ("Führer") Pight and to "the German world" mired in "damnable hypocrisy, lies, and deception." 40 The trope of the noble savage is clearly at work here. The Leipzig sources for 1723 also note that Ocktscha Rinscha and Tuski Stannaki were skilled at finding their way in the countryside, even in unfamiliar areas. They could "learn the streets and lanes of a city in the blink of an eye, and do not easily get lost." It is not clear, however, whether these accounts simply repeated essentialist tropes about Native people or drew upon actual observation. We are also told they had a special liking for Saxony, especially Dresden. ${ }^{41}$

After the Leipzig winter trade fair, Pight and the two captives returned to Dresden. They had an audience with Augustus II at some point, though it is not clear exactly when this happened. ${ }^{42}$ The first report of Pight's interest in selling the two Native men to the King appeared in December 1722, and sometime in the summer of 1723, Augustus bought them and agreed to pay for their room and board at the Golden Crown. ${ }^{43}$ They thus became the property of the Polish King and members of the Saxon court. Meanwhile, Pight returned to Carolina, where he was on his deathbed when he made his will in 1726.

In all, Ocktscha Rinscha and Tuski Stannaki spent about three years in Dresden. They began to study German and prepared to convert and become Lutheran

37 Kurtzgefastes sächsisches Kern-Chronicon 3 (1722/23): 38. On Electoral Saxony in this era, see Frank-Lothar Kroll and Hendrik Thoss, eds., Zwei Staaten, eine Krone: Die Polnisch-Sächsische Union 1697-1763 (Berlin: Bebra Wissenschaftsverlag, 2016) and Karl Czok, August der Starke und seine Zeit: Kurfürst von Sachsen, König in Polen, 3rd ed. (Leipzig: Edition Leipzig, 1997).

38 This was at the same time that Johann Sebastian Bach came to Leipzig to perform his test pieces (Cantatas nos. 22 and 23) on February 7, 1723, as part of his application for the position as cantor of the Thomasschule.

39 Principally the Leipzig Spectateur 3 (1723): 145-152; the Acta Lipsiensium academica 1 (1723): 85-87; the Kurtzgefastes sächsisches Kern-Chronicon 3 (1722/23): 35-38; and the Leipziger Jahr-Buch, January 1723, 441.

40 Leipziger Spectateur 3 (1723): 151. The Spectateur report claims that Pight would not allow the men to be educated or learn anything of Christianity "so that his profits may not escape him" ("damit ihm sein Gewinn nicht entgehe").

41 Leipziger Spectateur 3 (1723): 150.

42 No audience is recorded in the Dresden court journals for 1722 or 1723, and the journals are missing for 1724-1733.

43 So far, no record of their purchase has been found. 
Christians, aided by David Mehner, a theology student. The Breslau Sammlung reported in March 1724 that "the two American Princes who were brought here in 1722, purchased by His Royal Majesty, and taken in by His court, now frequent the worship services in the Protestant Palace Church. One hopes that they will soon convert from paganism.” A similar report appeared in the London Daily Courant on April 14, 1724. ${ }^{44}$

In Dresden, we can see more clearly how Ocktscha Rinscha and Tuski Stannaki shaped their own lives. They learned to speak German "nearly as well as nativeborn Saxons," freeing themselves from the isolation imposed by Pight. ${ }^{45}$ They expressed interest in Christianity and were quickly repaid with the attention of the city's Lutheran clergy. Assisted by Mehner and other Lutheran pastors, they learned "the whole of Christian doctrine" and could "confidently answer more than 450 questions" about it. By 1724 they were prepared to be baptized and made repeated requests to this end to Valentin Ernst Löscher, the Protestant Superintendent in Dresden, as well as to "other Lutheran pastors in the area" for over a year. ${ }^{46}$ As John Jeremiah Sullivan noted, whether they were drawn by "the light [. . .] of Christ, [. . .] or whether it was simply the light of kindness," Ocktscha Rinscha and Tuski Stannaki had found a community they wanted to join. ${ }^{47}$ Perhaps they thought conversion to Christianity would liberate them from slavery, or they simply gave in and adopted the religion of their captors. In any case, the two battle-scarred warriors had found important allies among the Lutheran clergy of Dresden.

But Augustus II, the Catholic King of Poland and owner of the two men, never responded to any of their requests to be allowed to become Protestant Christians. Although he was personally indifferent to religious questions, the Lutherans in Dresden were convinced that Augustus refused Ocktscha Rinscha and Tuski Stannaki permission to convert because his "Roman clergy want them for themselves." 48 Competition for the sacred duty (and glory) of converting the two "heathens" to Christianity created a political standoff between Augustus' clergy and the Lutheran clergy of Dresden. In May 1725, the two prospective converts petitioned the Upper Consistory, the highest clerical authority in Electoral Saxony, for permission to be baptized, pleading that "the great God, who has led us out of the thickest heathen darkness, would certainly [. . .] not let such a great blessing, which we value above all things, go unrewarded." 49 The Upper

44 Sammlung von Natur- und Medicin-[. . .] Geschichten [for 1724] 27 (1725): 316. On April 14, 1724 the London Daily Courant reported that "the two American Princes who came hither in the Year 1722, and have since been taken Care of by his Majesty, do now frequently assist at the Divine Service in the Protestant Chapel of the Palace, so that it is hoped they will shortly renounce Paganism and embrace the Protestant Religion.”

45 Kurtzgefastes sächsisches Kern-Chronicon 6 (1725/26): 560.

46 Hauptstaatsarchiv Dresden, 10025 Geheimes Konsilium, Loc. 4692/07, fol. 10r-13r.

47 Sullivan, "The Princes: A Reconstruction,” 67.

48 Theodor Wotschke, “Oberhofprediger Marperger in Briefen an A.H. Francke," Zeitschrift für Kirchengeschichte Dritte Folge II, 51 (1932): 169-201, here 178.

49 Hauptstaatsarchiv Dresden, 10025 Geheimes Konsilium, Loc. 4692/07, fol. 10r-13r. 
Consistory immediately endorsed their request and forwarded the petition, which the Native men signed in their own hands as "most obedient servants, Ocktscha Rinscha; Tuski Stannaki" to the King-Elector. Again, there was no response. By the spring of 1725, Dresden's Lutherans had also heard the ominous claim that Ocktscha Rinscha and Tuski Stannaki "had no freedom of religion because they were purchased with money as serfs [Leibeigene]." 50

In the fall of the same year, the Native American men learned that Augustus intended to summon them to his court in Warsaw for instruction in the Roman Catholic religion. Only then, after an unspecified period of Catholic education, would they be allowed to choose to be baptized as Lutherans. ${ }^{51}$ This move afforded Ocktscha Rinscha and Tuski Stannaki the appearance of freedom of religion, but given their dependence on Augustus, in reality it meant that they would almost certainly become Catholic. With the date of their departure from Dresden approaching, the Lutheran clergy of the city, led by Superintendent Valentin Ernst Löscher, felt they had no choice: They arranged to baptize the two men in Dresden's Kreuzkirche on October 6, 1725 at seven in the evening - an unusual time for an unplanned ceremony, which took place "furtively" and "with the church doors locked [. . .] in an irregular form [and] at an irregular time." 52 The attending clergy and their wives served as godparents: Ocktscha Rinscha took the name Friedrich Christian and Tuski Stannaki the name Augustus Christian.

Augustus was unsurprisingly unhappy with his Lutheran clergy for what sounds like an almost clandestine ceremony - unlike the baptisms of other adult "pagans" or Muslims in Saxony and the Empire, there was no announcement prior to the event, nor any triumphant publication about it afterward. ${ }^{53}$ The King-Elector ordered the men to be brought to Warsaw as planned; in the meantime, for fear that they might flee Dresden, they were kept under guard. They departed Dresden on October 11, 1725 after "a tearful farewell from their priestly godparents" 54 and traveled to Warsaw by way of Breslau; their next trace in the historical record is a report that they were living in a monastery in Warsaw in December $1725 .^{55}$

50 Wotschke, "Oberhofprediger Marperger," 178.

51 Wotschke, "Oberhofprediger Marperger," 183.

52 Hauptstaatsarchiv Dresden, 10026 Geheimes Kabinett, Loc. 00717/07, fol. 25r-v: "bey verschloßenen Kirch-thüren zu tauffen, ohne daß man vorher weder bey den OberConsistorio noch weniger bey dem Geh. Consilio deßhalber angefraget. Und ist kein Zweifel, daß man dieses Unternehmen, welches auch eine so ungewöhnliche Arth, zu einer ganz ungewöhnlichen Zeit und mithin gleichsam verstehlner weise geschehen [. . .]".

53 See Markus Friedrich, “'Türken' im Alten Reich: Zur Aufnahme und Konversion von Muslimen im deutschen Sprachraum (16.-18. Jahrhundert),” Historische Zeitschrift 294, no. 2 (2012): 329-360.

54 Kurtzgefastes sächsisches Kern-Chronicon 6 (1725/26): 574.

55 Franckesche Stiftungen Halle, Nachlass A. H. Francke 9/17: 1, "Brief von Christian Gerber an August Hermann Francke." 


\section{Poland}

Evidence of the lives of Ocktscha Rinscha and Tuski Stannaki at the court of Augustus II in Warsaw was first discovered in the summer of 2019 in the court personnel books. ${ }^{56}$ In all previous research on Ocktscha Rinscha and Tuski Stannaki, their story ended when they left Dresden in October 1725. The published report of their departure claimed that the King-Elector planned to give the two men to Catherine I, Empress of Russia. ${ }^{57}$ This unsubstantiated assertion seems to have deterred research into the lives of the two men in Saxony or Poland after 1725. In fact, by 1726, Ocktscha Rinscha and Tuski Stannaki had become servants at the Polish royal court in Warsaw.

A series of entries in the court personnel books ("Hofbücher") of the SaxonPolish court allows us to sketch another chapter in the lives of these resilient men. They first appear in the staff records for the period 1726-1729 as Friedrich Christian and August Christian; their positions at court are each listed as "Indian" [!], with an annual salary of 120 Reichsthaler. The personnel book for 1730-1733 indicates that "Augustus Christian, otherwise an Indian, brought to Dresden in 17xx [sic], from Virginia" became a liveried court messenger in May $1730 .^{58}$ The older man, Ocktscha Rinscha/Friedrich Christian, remained in his position as "Indian." Several entries in these same records note that their religion was Roman Catholic. ${ }^{59}$

In his role as a messenger, "August Christian, otherwise Stannagé” seems to have been more deeply integrated into court life. But this was to change: On January 1, 1733, Ocktscha Rinscha/Friedrich Christian died in Warsaw only a month before his master, King-Elector Augustus II. A year later, Tuski Stannaki/August Christian was still serving as a court messenger, now with a higher salary of 168 Reichsthaler per year. The last known trace of him is found in the Saxon court personnel roster for 1734, which declares simply that he "escaped ["ist entlaufen"] from the court with his livery during the 1734 Easter trade fair." 60 This brief statement raises an array of questions: Why did Tuski Stannaki flee from his position at court after eight years of service? Did the trip to Leipzig create a new opportunity to flee while in German-speaking Saxony? Did the deaths of Ocktscha Rinscha or King Augustus II in 1733 impel him to leave the court? Were his godparents and Lutheran allies from Dresden involved in his escape? How and where did he live after fleeing? More research should uncover further evidence

56 This discovery was entirely the work of Rebekka von Mallinckrodt, to whom I am most grateful. She discovered these references to Ocktscha Rinscha and Tuski Stannaki while pursuing her own research on Africans at the Saxon court.

57 Kurtzgefastes sächsisches Kern-Chronicon 6 (1725/26): 574.

58 Hauptstaatsarchiv Dresden, 10006 Oberhofmarschallamt, K 02, Nr. 7: "August Christiani, sonst ein Indianer, so 17. [sic] nach Dresden bracht worden; aus Virginien [. . . ] Livrée [. . .] ist Lauffer worden.”

59 Hauptstaatsarchiv Dresden, 10006 Oberhofmarschallamt, K 02, Nr. 8.

60 Hauptstaatsarchiv Dresden, 10006 Oberhofmarschallamt, K 02, Nr. 13: "Ist in der OsterMeße 1734 zu Leipzig von der Hof Stadt mit der Livrée entlaufen." 


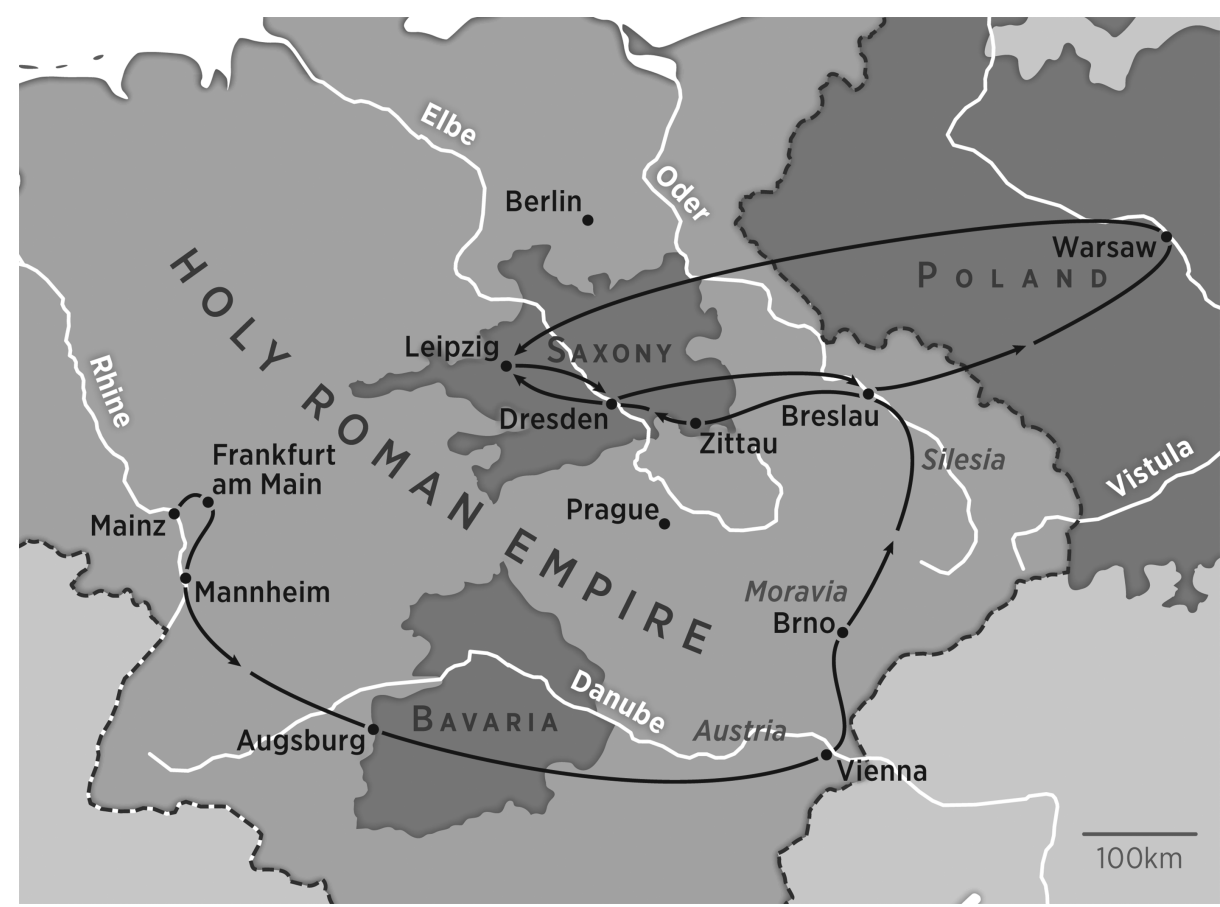

Fig. 3.6: Ocktscha Rinscha and Tuski Stannaki in the Holy Roman Empire and Kingdom of Poland, 1722-1734. Map by Daniel P. Huffman.

on the lives of both men at the Polish-Saxon royal court from 1726-1733/34 as well as on the life of Tuski Stannaki/Augustus Christian in Central Germany after he escaped from the court in 1734.

\section{Skin and Slavery in the Holy Roman Empire}

The lives of Ocktscha Rinscha and Tuski Stannaki reveal the imprint of Atlantic slavery on eighteenth-century German culture. As John Jeremiah Sullivan has observed, these men were extraordinary in early modern Germany and Poland - likely the first Native Americans ever seen, or perhaps even imagined, in Saxony or Silesia. The rich documentation of the time they spent in Central Europe illustrates a surprising set of cultural traces of the slave trade in the German-speaking lands during the early eighteenth century. As I will show, one pattern emerges immediately: African slavery functioned as an invisible template of sorts that shaped almost every 
aspect of the German accounts of the Native men. ${ }^{61}$ This is especially apparent in the responses to their richly ornamented bodies and to their status as slaves. In the German sources, the connections between skin, slavery, and race reflect key developments in the history of early modern epidermalization.

In an ethnographic or heuristic sense, epidermalization describes the fixing of social meaning on the skin through culturally and historically specific practices and discourses. ${ }^{62}$ When a society's most important quotidian markers of status, gender roles, life experience, and aesthetic expression appear on the skin (rather than on clothing, in a set of identification documents, or by way of one's possessions), one can say that the society in question is highly epidermalized. This was the case for most of the West African and American societies encountered by Europeans in the Atlantic World. Skin marking practices (dyeing, tattooing, piercing, and scarification) were widespread, positive signs of inclusion, often with deep aesthetic value. Deliberate marks on African and American skin were signs of adulthood, beauty, bravery, or political affiliation. They connected people and displayed status; some offered protection against disease, witchcraft, and other harms.

When Europeans began to sail the Atlantic in the fifteenth and sixteenth centuries, they entered this world of honorably marked skin, encountering a wide range of highly epidermalized societies on both sides of the Atlantic. In their earliest reports of West African and Native American peoples, Europeans noted and described skin markings as a sign of difference at least as significant as any contrast of skin color. Indelible skin marking was already associated with the New World when the Italian Alberto Cantino described the Native people brought from Newfoundland to Lisbon in 1501: "I have seen, touched, and examined them [. . . ] they have faces marked with large signs, and the signs are like the signs of the Indians [i.e., natives of the Caribbean]." Writing from Valladolid in 1520, the ambassador Francesco Corner reported that the Mayans brought to Spain were "very deformed by images and each pierced in the chin."63

61 One can see this template, for example, in the translator's afterword to Afra Behn, Lebens- und Liebes-Geschichte des Königlichen Sclaven Oroonoko in West-Indien: mit ihren wahrhafften und merckwürdigen Umständen, trans. M. $V^{\star \star}$ [Ludwig Friedrich Vischer] (Hamburg: Wiering, 1709), [199ff.]. Here the translator, Ludwig Friedrich Vischer, explains to readers that if the extraordinary resistance to torture endured by the enslaved African Oroonoko seems incredible, they should consider the evidence of Iroquois resolve in response to pain and torture as described in Baron de Lahontan's two-volume travel account Nouveaux Voyages de M. le Baron de Lahontan dans l'Amérique septentrionale and Mémoires de l'Amérique septentrionale, which Vischer had recently translated into German as Des berühmten Herrn Baron De Lahontan Neueste Reisen nach Nord-Indien oder dem mitternächtischen America (Hamburg: Reumann, 1709).

62 The term is introduced in Frantz Fanon, Black Skin, White Masks, trans. Charles Lam Markmann (Grove Press: New York, 1967), 11-13.

63 Geoffrey Symcox and Giovanna Rabitti, Italian Reports on America, 1493-1522: Letters, Dispatches, and Papal Bulls (Turnhout: Brepols, 2001), 55, 78. Cantino was an agent in Lisbon for Ercole d'Este (1431-1505), Duke of Ferrara. 
When Europeans encountered skin adorned in this manner with signs of honor, status, ornament, or inclusion, they had few direct reference points. In the fifteenth and sixteenth centuries, Europeans themselves regarded the skin primarily as the body's container and covering, "said to contain more easily the parts which be within, and also to hinder and withstand the outer griefs." ${ }^{64}$ Deliberate, permanent marking of the skin was relatively rare and generally dishonorable: The three most common expressions of the idea of the indelible dermal mark were penal branding (on the cheek, hand, chest, or shoulder), the (putative) witches' mark, and the stigmata (themselves originally a mark of punishment). ${ }^{65}$ Classical and Christian traditions alike condemned permanent physical marking of the skin and associated it with slavery and punishment: "When a burning iron is put on the face of a evil-doer, it leaveth behind it a brand, or a stigma," as a Scottish minister explained in $1652 .{ }^{66}$ Early modern Europeans could scarcely imagine a European form of permanent skin marking that reflected social superiority or aesthetic expression. Such a mark would be an "honorable stigma" - an oxymoron.

In the sixteenth century, European accounts of deliberate, permanent marks on African and American skin began to emphasize that - contrary to European expectations - such marks were signs of honor and status. While a captive of the Tupinambá in Brazil in 1553, the German soldier Hans Staden noted the ritual of passage to adulthood for women:

when they [the daughters] have reached the age when they begin to share the customs of women, they [the Tupinambá] then cut off the hair from the heads of the young women, [and] scratch peculiar marks on their backs [. . .] Afterwards when their hair has grown out again, and the cuts have healed, you can still see the scars where they were cut, for they put something in there [in the wounds], so that they remain black when they have healed. ${ }^{67}$

Staden understood the Tupinambá language and culture sufficiently to conclude that "they consider this to be a [sign of] honor." 68 And at the apex of honor stood nobility: In 1564, Robert Gainsh reported from the Gold Coast that "touching the manners and nature of the people, this may seem strange, that their princes and

64 Stephen Batman, Batman uppon Bartholome, his booke De proprietatibus rerum (London: Imprinted by Thomas East, dwelling by Paules wharfe, 1582), fol. 68v.

65 Battle scars might be considered badges of honor, but they were not intentionally applied. In everyday life, such scars were difficult to distinguish from scars caused by accidents, or from the dishonoring marks of penal branding.

66 Samuel Rutherford, The Tryal \& Triumph of Faith: Or, an Exposition of the History of Christs Dispossessing of the Daughter of the Woman of Canaan Delivered in Sermons (London: printed by John Field, and are to be sold by Ralph Smith, at the sign of the Bible in Cornhill neer the Royall Exchange, 1652), 283.

67 Michael Harbsmeier and Neil L. Whitehead, eds. and trans., Staden's True History: An Account of Cannibal Captivity in Brazil (Durham: Duke University Press, 2009), 123.

68 Harbsmeier and Whitehead, Staden's True History. 
noble men use to pounce and rase their skins with pretty knots in divers forms, as it were branched damask, thinking that to be a decent ornament." 69 Describing the men of the Grain Coast (the western coast of the Gulf of Guinea), Johann von Lübelfing noted that "around their chest and all over their back their skin was pricked in the same way as a tailor pricks a silk doublet. Those who adorn themselves thus no doubt consider themselves somewhat nobler than the others." "70 Skin markings that seemed especially extensive or "showy" were often compared by Europeans to clothing and the social hierarchy it was supposed to indicate. In other words, elaborate skin markings were seen as a sign of indigenous nobility: Europeans were beginning to understand epidermalization.

It was the extraordinary marks on the bodies of his captives that inspired Pight to bring them from Carolina to Europe. To enhance interest, he billed them (speciously) as "princes" and claimed that the marks borne by the men were proof of their royal status. He further alleged that the "hieroglyphic figures and Indian letters" on the men's skin displayed (to others of their culture) "their various families and the military victories of their ancestors."71 As living examples of honorable and aesthetic epidermalization, Ocktscha Rinscha and Tuski Stannaki attracted intense interest from German viewers who sought to form their own understanding of such dermal practices. German responses to the Native men cited both popular travel writing and learned Latin publications as well as hands-on inspections (see below). When they assessed the dermal marks and their bearers, however, observers in Breslau and Leipzig quickly challenged Pight's claims regarding the nobility and legibility of the Native marks.

The Leipziger Spectateur doubted that the "very detailed" ("accurat") tattooed figures were any sort of language or hieroglyphics ("as the printed handbill states"), arguing instead that "they are drawn on them in their tender youth, when they are about 7 or 8 years old. The [parents] sketch out the figures according to their imagination [Phantasie]."72 The claim that the individual marks on Ocktscha Rinscha and Tuski Stannaki were applied in childhood and merely decorative also appears in a Dutch report on the men from 1720:

Paris, July 29. Two American Princes have arrived for a few days. People say that one is the son of an emperor and the other is the son of king whose lands surround the Mississippi River.

\footnotetext{
69 Robert Gainsh, “The Second Voyage to Guinea,” in Richard Hakluyt, The principall navigations, voiages and discoveries of the English nation (London: George Bishop and Ralph Newberie, 1589); modern facsimile, ed. David Beers Quinn et al., vol. 1 (Cambridge: Cambridge University Press, 1965), 90-97, here 96 (italics added; spelling modernized).

70 Adam Jones, ed., German Sources for West African History 1559-1669 (Wiesbaden: Steiner, 1983),

12, describing a voyage in 1599-1600.

71 Wienerisches Diarium, May 20, 1722.

72 Leipziger Spectateur 3 (1723): 147.
} 
Their bodies are full of imaginative characters, which were imprinted on them in childhood and became larger as they grew into adulthood. ${ }^{73}$

By classifying Ocktscha Rinscha and Tuski Stannaki’s marks as “imaginative” or "pictorial," reflecting only the "fantasy" or "imagination" of their parents, the marks are stripped of their personal character and cannot reflect any adult accomplishments or achievements of the men. "I do not believe," wrote the Spectateur author, "that the figures [on the men] represent hieroglyphics or Indian letters [Caracteres]."74 This denial of intelligibility contrasts with the first English reports from Virginia mentioned earlier as well as with Pight's description of their "hieroglyphics."

When Pight described the marks on Ocktscha Rinscha and Tuski Stannaki as "hieroglyphic figures and Indian letters," he reflected a long-standing English awareness of the intelligibility of such marks. As Mairin Odle has shown, seventeenth-century English colonists imagined Native Virginian markings as a kind of "permanent livery" showing the origins and political affiliations of their bearers through hieroglyphic symbols (see Fig. 3.7). ${ }^{75}$ On the one hand, the social order and hierarchy the English saw in these Native body markings was reassuringly familiar. As Joel Konrad has noted, this interpretation of the marks "demonstrated the extent to which the Virginians, though 'savage,' maintained a clear social hierarchy. With little clothing, the emblems of fealty must necessarily be emblazoned upon the skin, a clear indication of comprehendible hierarchy and willingness to be ruled."76 On the other hand, the marks revealed "what Princes subjects they be, or of what place they have their original [ethnic origin]" only to other Native people. The English could not decipher or read them directly, which was troubling for several reasons. On a practical level, the English could not use the markings to recognize allies or enemies. On a more abstract level, the systems of dermal marking were clear evidence of ways of knowing and communicating that were beyond European grasp.

The Leipziger Spectateur reported skeptically that Pight claimed the quantity and quality of marks on the men was a sign of their noble status as "true princes." The published Breslau account took this skepticism even further, reasoning that the degree of marking on Ocktscha Rinscha and Tuski Stannaki was probably not a sign of nobility because "among these Americans such bodily inscriptions are received

73 Oprechte Haerlemsche Courant, August 3, 1720: "Parijs den 29 July. Voor eenige dagen zijn 2 Americaensse Princen aengekomen: Men zegt, dat d'eene een soon van een Keyser en d'ander een Soon van een Coning is, welckers Landen, aen de Rivier Mississippi leggen; en dat haer Lighamen vol beeldsprakelijcke Characters zijn, die in haer kindsheyd op haer gedrukt werden, en ook grooter werden, na mate dat de Personen in waschdom toenemen.”

74 Leipziger Spectateur 3 (1723): 147-148.

75 See Mairin Odle's forthcoming monograph Skin Deep: Tattoos, Scalps, and the Contested Language of Bodies in Early America (Philadelphia: University of Pennsylvania Press).

76 Joel Konrad, “'Curiously and Most Exquisitely Painted': Body Marking in British Thought and Experience, 1580-1800” (PhD diss., McMaster University, 2011), 53. 
as signs of citizenship [Bürgerrecht] and are entirely common."77 In contrast to earlier associations of skin marking with nobility, as emphasized by Pight, these central European observers read and learned that marked skin was a broader sign of membership in a polity, open to almost everyone in the respective ethno-political group. Likewise, the German (and Dutch) accounts pushed the time of skin marking back into the childhood of the men so that it became a generic marker received from their parents - almost like race. These assertions in the Breslau and Leipzig reports on Ocktscha Rinscha and Tuski Stannaki emphasize dermal marking as inborn and thus associated more with nature and less with culture. This sense of inborn dermal marking, much sharper than in the previous century, allowed Europeans to erase or overlook its hieroglyphic character and its personal specificity. The ability to reinterpret the marks on the skins of these men shows how far the European understanding and use of epidermalization had come. European commentators transformed intricate African and American dermal signs that were incomprehensible to European eyes into marks of nature and "imagination." By effacing the cultural and personal expression of the tattoos on Ocktscha Rinscha and Tuski Stannaki, two distinct people from two different Native cultures, the men were transformed into generic "wild" Indians or "American princes," commodified for their skin markings and kept as slaves. Even their acceptance of the "invisible mark" of baptism did not truly affect this status.

The legal status of Ocktscha Rinscha and Tuski Stannaki as slaves was never questioned. In all the initial accounts of the men, their owner, the "English shipcaptain named Pecht" (i.e., John Pight), was right there, carefully managing access to them. The Breslau Sammlung notes that when the "Princes" arrived in Dresden, "their master ("Maître") was willing to sell them for 1000 Thaler cash," while the Leipziger Spectateur speaks matter-of-factly of "their way of life when they were still free." ${ }^{\text {78 }}$ Private and official documents also affirmed their slave status. In the fall of 1725, Bernhard Walther Marperger, the Senior Court Preacher (Oberhofprediger) in Dresden, wrote to August Hermann Francke regarding "the two American princes whom the King bought as slaves."79 In their own petition to be baptized, submitted in May 1725, Ocktscha Rinscha and Tuski Stannaki do not refer to themselves as slaves, writing simply as "we poor and distressed foreigners." But the angry inquiry by the King-Elector about the Lutheran baptism of the two men refers to "the two Americans we purchased as slaves some time ago."80

We know from a growing body of scholarship (including other contributions to this volume) about the uncertain legal and quotidian status of many Africans in

77 Sammlung von Natur- und Medicin-[. . .] Geschichten [for 1722] 21 (1724): 315.

78 Sammlung von Natur- und Medicin-[. . .] Geschichten [for 1722] 22 (1724): 705, and Leipziger Spectateur 3 (1723): 146: "Ihre Lebens Art, als sie noch frey gewesen."

79 Wotschke, “Oberhofprediger Marperger,” 183.

80 Hauptstaatsarchiv Dresden, 10025 Geheimes Konsilium, Loc. 4692/07, fol. 2r: "wir arme betrübte Frembdlinge” and fol. 5v: “die beyden Americaner, so Wir vor einiger Zeit als Sclaven erkaufft.” 


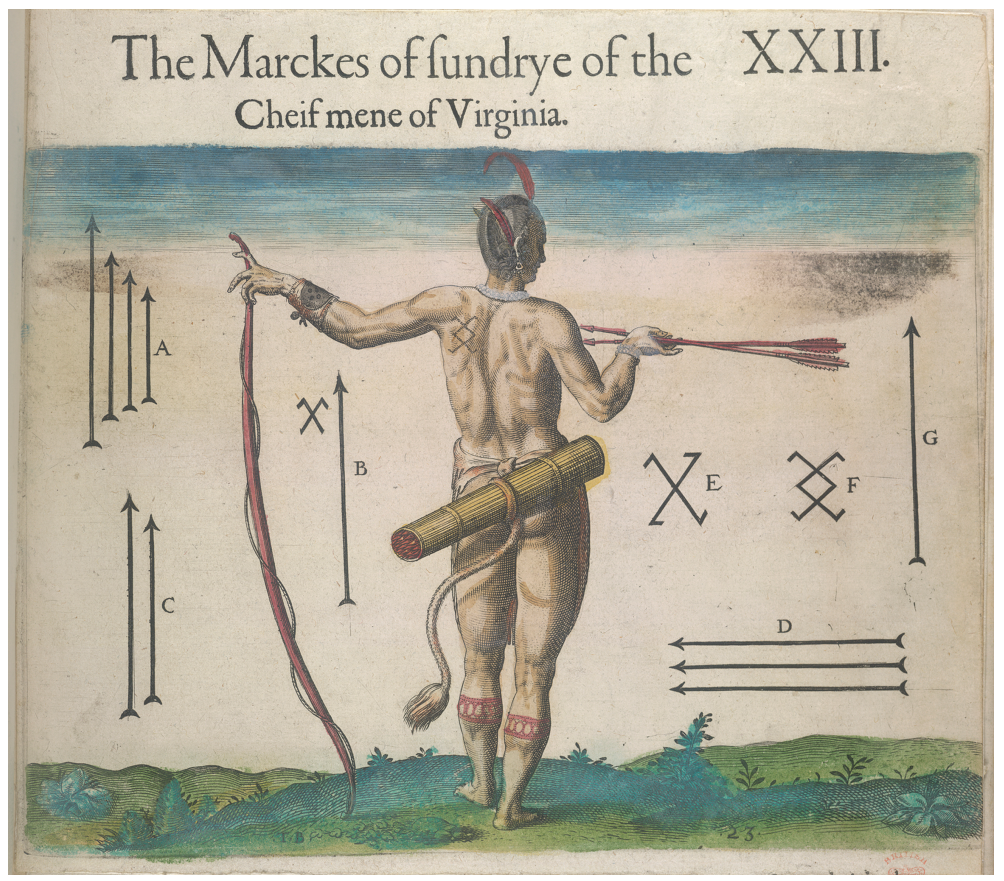

Fig. 3.7: Illustration by Theodor de Bry for Thomas Hariot's A Briefe and True Report of the New Found Land of Virginia (Frankfurt: Theodor de Bry, 1590). (C) The British Library Board.

early modern Germany - balanced between slave and servant, between dependent and employee, sometimes entering service as a "gift" like property, in other cases hired and paid like other court personnel. In the case of Ocktscha Rinscha and Tuski Stannaki, there was no doubt: Their owner was Herr Pecht, who came from a place where the line between employee and slave was drawn very sharply indeed. And as their owner, he "offered them for purchase to His Majesty in Poland, our most gracious Lord, for 1000 Rthl." 81

The men were slaves because they had been "captured by their enemies in battle." 82 Their Native captors "had the right, according to the customs of the land, to kill them," but had preferred to deliver them over to "an English captain." ${ }^{83}$ Pight was their owner because he had obtained them as prisoners of war from other Native Americans (Leipziger Spectateur) or because he had captured them himself at sea and taken them as "Prisonniers de guerre" (Breslau Sammlung and the Leipziger Jahr-Buch). In any case, the accounts from Breslau, Leipzig, and Dresden allowed

81 Leipziger Spectateur 3 (1723): 150.

82 Leipziger Spectateur 3 (1723): 146.

83 Leipziger Spectateur 3 (1723): 146. 
Germans to rehearse the familiar justification for trade in enslaved Africans. The claim that Black slaves had already been legitimately enslaved in Africa according to African customs and in accord with the law of war was transferred to the more tangible context of Pight and his captive Americans. By the 1720s, there were growing objections to the absurd extension of the law of war to include the enslavement of African women and children as well as to justify hereditary slavery. ${ }^{84}$ But Pight's captives were "clearly" his, taken as adult fighting men - effectively an "ideal case" in the justification of Atlantic slavery. Oddly, the German accounts are less clear on the role of Pight himself: He styled these men as "princes," but Germans also understood that they were his captives. He is never (as far as I have been able to find) referred to as their master ("Herr") or owner ("Besitzer") - instead, the reports call him the "Patron," "Führer," or "Maître" of Ocktscha Rinscha and Tuski Stannaki.

No one seems to have challenged the two Native Americans' enslavement as such. After Pight sold the men to Augustus II sometime in 1723, their legal status did not change as far as we can tell. Later, when the struggle over their desire to be baptized as Lutheran Christians commenced, some of Ocktscha Rinscha and Tuski Stannaki's supporters claimed that when the "English Captain sold them to our King [. . . ] the King is supposed to have promised to give them complete freedom of religion." ${ }^{85}$ There is no record of the sale or any conditions that might have accompanied it, however.

Nor has anyone found any evidence of the men's legal emancipation: Neither their purchase by the King-Elector nor their baptisms in October 1725 had any effect on their status. As noted above, supporters of Augustus' authority over Ocktscha Rinscha and Tuski Stannaki claimed that the Native men "had no freedom of religion, because they were purchased with money as serfs ["Leibeigene"]" ${ }^{86}$ Designating the men as "serfs" rather than slaves may have lent this claim more legal precedent. Despite the assertion that they were unfree, Ocktscha Rinscha and Tuski Stannaki did choose to receive baptism, and Saxony's Lutherans celebrated the freedom brought by the sacrament:

Dresden has indeed never experienced the joy of seeing heathen princes among them, much less of accepting them into their community and church. They have now been freed not only

84 For example, in the German translation (1709) of Aphra Behn's Oroonoko one reads that Imoinda "wept and sighed over the servitude of her husband and unborn child" ("über ihres Gemahls und ungeborenen Kindes Knechtschafft zu weinen und zu seuffzen”), evoking the question of hereditary slavery. Behn, Lebens- und Liebes-Geschichte, 122.

85 Franckesche Stiftungen Halle, Nachlass A. H. Francke 9/17: 1, "Brief von Christian Gerber an August Hermann Francke," [fol. 2v]: "Die beyde Americanischen Prinzen stecken nun leider zu Warschau auf im Kloster. Wenn doch Dero [J.] Kön. Maj. in Engell. ins Herz gäbe, sich dieser Prinzen anzunehmen, weil sie [?] ein Engell. Capitain an unsern König Verkaufft habe, u. der König Versprochen haben soll, Ihnen moge der Religion alle Freyheit zulassen.”

86 Wotschke, “Oberhofprediger Marperger,” 178. 
from physical slavery but also from their spiritual slavery. They have now become fellow citizens in Christ's kingdom and our brothers. ${ }^{87}$

This claim that the men were "freed not only from physical slavery but also from their spiritual slavery" appears only in this single journal report and does not seem to reflect any actual change of status. Even if Ocktscha Rinscha and Tuski Stannaki were considered "as free as" other members of the court, that meant that they were being fed, clothed, and sheltered in the extended household of the King. Baptized Lutherans or not, they still "belonged to the court" and could not ignore the royal summons to Warsaw. ${ }^{88}$

During their time in Poland, about which we know little, the men seem to have made two significant transitions: from Lutheran to Roman Catholic, and from ad hoc members of the court living in a Dresden inn to true court servants - paid, employed, and registered alongside many others in the court personnel books. Their undefined status as slaves, serfs, or servants at court left them in the state of "privileged dependency" so typical for African court personnel in the Empire under the Old Regime. ${ }^{89}$

If the references to Ocktscha Rinscha and Tuski Stannaki as lawfully enslaved prisoners of war allowed Germans to reiterate a key justification for Atlantic slavery, then the thorough bodily examinations to which the men were subjected seem to have enabled the rehearsal of another key aspect of the Atlantic slave trade, namely the inspection of enslaved bodies for sale. To understand these marked and enslaved bodies, the German observers sought the closest possible access to the skin. The Breslau author reports that "one pinched, scratched, and rubbed with a moistened finger on the lines [tattoos], but the color did not change at all." In the Leipziger Spectateur, we likewise read of a very close, hands-on inspection of the skin of the two men, which concluded that "the figures are just slightly raised above the second skin [i.e., the dermis]." In Breslau, study of the Native Americans' skin brought the determination that "the pigment of these characteristic [marks] was [set] so firmly and deeply in the cuticula [epidermis] that one could not perceive the slightest trace of any smearing of it."90 Their hair also fascinated observers: According to the Breslau report, "the hair [. . .] was not only coal black, but it also had the same consistency - in thickness, strength, and hardness - as

87 Kurtzgefastes sächsisches Kern-Chronicon 6 (1725/26): 559-562.

88 Wotschke, “Oberhofprediger Marperger," 184.

89 Vera Lind, "Privileged Dependency on the Edge of the Atlantic World: Africans and Germans in the Eighteenth Century," in Interpreting Colonialism, ed. Byron R. Wells (Oxford: Voltaire Foundation, 2004), 369-391. See Arne Spohr, “'Mohr und Trompeter': Blackness and Social Status in Early Modern Germany," Journal of the American Musicological Society 72, no. 3 (2019): 613-663, and the literature cited there.

90 Leipziger Spectateur 3 (1723): 148; Sammlung von Natur- und Medicin-[. . .] Geschichten [for 1722] 21 (1724): 313. 
horsehair." The bodily invasion suffered by the men whenever "on display" is especially vivid when we read that the Breslau authors "pulled back and held together the entire mass of hair" of one of the men, and that "it was just like holding the tail or mane of a horse." 91

In their "inspections" of Ocktscha Rinscha and Tuski Stannaki, the curious observers encountered only one barrier - and their repeated attempts to cross it reveal their expectations regarding access to commodified bodies. As the author of the Leipziger Spectateur explained: "I have often been amazed by the singular curiosity of people viewing these princes, because I have often seen them while in the company of others who have inquired about the nature of their genital members." 92 Indeed, the Breslau authors remarked with regret that "one could not see any of the genitalibus, although one would have gladly, in order to investigate whether these princes might be circumcised." ${ }^{93}$ Like the purchasers of slave bodies, these curious men expected unfettered access to the Native American bodies they had just paid "ein Sieben-Creutzer" (about four pence) to examine.

The excruciatingly close physical inspections call to mind both the precise anatomical work being performed at the time on African skin (in London, Leiden, or Paris) to uncover the empirical basis of "African Blackness" and the daily, brutal inspection of enslaved bodies for purchase (in Hueda or Bunce Island, Cartagena or Charleston). These two aspects of Atlantic slavery - the scientific/ideological and the quotidian/commercial - were carefully separated from one another in the vast Atlantic empires of the Spanish, Dutch, British, or French. But when we search for traces of the Atlantic slave trade in the Holy Roman Empire, examining both the trafficking of people like Ocktscha Rinscha and Tuski Stannaki and the discursive engagement with skin and slavery they evoked, these typically separate (or separated) aspects of the trade come together. The opportunity to see disparate aspects of Atlantic slavery together in a tighter frame - to see practices of knowledgemaking and profit-making collide, for example - means that the study of slavery in the Empire can deepen our understanding of early modern slavery everywhere.

\section{Conclusion}

The rich evidence of the lives of Ocktscha Rinscha and Tuski Stannaki described here can inform a range of issues in Native American, Atlantic, and Central European history. This essay has focused on changing relationships between skin, slavery, and race as fundamental to early modern epidermalization. From the sixteenth

91 Sammlung von Natur- und Medicin-[. . .] Geschichten [for 1722] 21 (1724): 314.

92 Leipziger Spectateur 3 (1723): 151.

93 Sammlung von Natur- und Medicin-[. . .] Geschichten [for 1722] 21 (1724): 313. 
to the eighteenth century, European accounts of permanent skin marking in the Atlantic World gradually shifted from describing them as a hieroglyphic sign of nobility (complex, intelligible, and reserved for only a few in a given society) to considering the marks as a merely symbolic or decorative - and thus ubiquitous - aspect of ethnic identity (marking all in a given society in similar ways).

The personal and unique dermal marks that in a sense made Ocktscha Rinscha and Tuski Stannaki the men they were serve as an example of traditional epidermalization. But German observers also noted the color of the skin on which the marks had been made. Either soot or the juice of some "American root" was used to make the marks permanent, the Leipziger Spectateur explained, noting that the bluish figures "do not look bad on a nearly coffee-colored body." 94 The Breslau Collection states that "their skin color was almost Gypsy-like, brownish or brown-yellowish." "95 In these reports, we see a fateful shift away from indigenous skin marking (once thought to contain hieroglyphics beyond European understanding) toward a notion of skin marked by one's parents - that is, like its actual color. This is an important step toward the consolidation of skin color as the defining attribute of a specific geographic, ethnic, or racial group. The German discussions of marked skin examined in this chapter show this transition, reflecting the culture of Atlantic slavery even in lands far from the trade itself.

When they entered Europe, the bodies of Ocktscha Rinscha and Tuski Stannaki were "painted over" by European associations of skin color and skin markings with slavery and race, just as their bodies had initially been covered with the personal, honorable markings of their own cultures. By reframing these markings as common to all their people (rather than being reserved for nobles) and as decorative products of imagination (rather than hieroglyphs of a written language) applied to them as children, the men were stripped of their individuality and refashioned as slaves. In this nascent European dermal regime, skin that was "unmarked" or "white" would come to signify privilege and mastery. The whiteness of a body marked as such would be received as a sign of citizenship ("Bürgerrecht") and become the common property or privilege of Europeans and their descendants (to rephrase the 1722 Breslau report quoted above). This development in the history of epidermalization bring us one step closer to whiteness as the Bürgerrecht of the West in the nineteenth and twentieth centuries.

94 Leipziger Spectateur 3 (1723): 148.

95 Sammlung von Natur- und Medicin-[. . . Geschichten [for 1722] 21 (1724): 312. Consistent with perceptions of Native American skin color in the early eighteenth century, no one ever refers to the skin color of the two Native men as red. See Nancy Shoemaker, A Strange Likeness: Becoming Red and White in Eighteenth-Century North America (Oxford: Oxford University Press, 2006), esp. 126-140. 


\section{References}

\section{Archival Sources}

Hauptstaatsarchiv Dresden 10006 Oberhofmarschallamt, K 02, Nr. 7, 8, 9, and 13. 10006 Oberhofmarschallamt, 0 04, Nr. 103. 10025 Geheimes Konsilium, Loc. 4692/07. 10026 Geheimes Konsilium, Loc. 00717/07.

\section{Printed Sources}

Acta Lipsiensium Academica: oder, Leipziger Universitätsgeschichte 1 (1723): 85-87.

Batman, Stephen. Batman upon Bartholome his booke De proprietatibus rerum. London: Imprinted by Thomas East, dwelling by Paules wharfe, 1582.

Battonn, Johann G., and Ludwig Heinrich Euler. Oertliche Beschreibung der Stadt Frankfurt am Main. Frankfurt: Verlag des Vereins für Geschichte und Alterthumskunde zu Frankfurt am Main, 1863.

Behn, Afra. Lebens- und Liebes-Geschichte des Königlichen Sclaven Oroonoko in West-Indien: mit ihren wahrhafften und merckwürdigen Umständen. Trans. M. V** [Ludwig Friedrich Vischer]. Hamburg: Wiering, 1709.

Ganish, Robert. “The Second Voyage to Guinea.” In Richard Hakluyt. The Principall Navigations, Voiages and Discoveries of the English Nation. London: George Bishop and Ralph Newberie, 1589. Modern facsimile ed. David Beers Quinn et al. Vol. 1, 90-97. Cambridge: Cambridge University Press, 1965.

Harbsmeier, Michael, and Neil L. Whitehead, eds. and trans. Staden's True History: An Account of Cannibal Captivity in Brazil. Durham: Duke University Press, 2009.

Kurtzgefastes sächsisches Kern-Chronicon, worinnen [. . .] etliche hundert merckwürdige alte und neue Glück- und Unglücks-Fälle, Festivitäten, Geburthen, Vermählungen und Absterben [. . .] bis hierher zugetragen [. . .] 3 (1722/23) and 6 (1725/26).

Leipziger Jahr-Buch, January, 1723.

Der Leipziger Spectateur: welcher die heutige Welt, der Gelehrten und Ungelehrten, [. . .] Leben und Thaten, Auch wohl Schrifften, beleuchtet und ihnen die Wahrheit saget 3 (1723): 145-152.

London Daily Courant, April 14, 1724.

Mercurii Relation, oder wochentliche Ordinari Zeitungen von underschidlichen Orthen, January 20, 1722.

Mercurii Relation, oder wochentliche Ordinari Zeitungen von underschidlichen Orthen, January 31, 1722.

Oprechte Haerlemsche Courant, August 3, 1720.

Oprechte Haerlemsche Courant, January 20, 1722.

Sammlung von Natur- und Medicin-, wie auch hierzu gehorigen Kunst- und Literatur-Geschichten so sich An. 1717 [-26] in Schlesien und andern Landern begeben [. . .] und ans Licht gestellet von einigen Bresslauischen Medicis 21-34 (1724-1727).

Stock, Johann Adolph. Kurtz gefaßte Franckfurther Chronik: In welcher das Denck- und Merckwürdigste, so sich im Jahr 742. nach unsers Heylandes Geburt biß auf unsere Zeiten allhie zugetragen. Frankfurt: Stock und Schilling, 1745.

The Weekly Journal or Saturday's Post, December 26, 1719. 
Whitehall Evening Post, January 13, 1722.

Wienerisches Diarium, May 20, 1722.

\section{Literature}

Avery, Emmett L., ed. The London Stage: 1660-1800: A Calendar of Plays, Entertainments \& Afterpieces together with Casts, Box-Receipts and Contemporary Comment [. . . ] Vol. 2, 1700-1729. Carbondale: Southern Illinois University Press, 1960.

Czok, Karl. August der Starke und seine Zeit: Kurfürst von Sachsen, König in Polen. 3rd ed. Leipzig: Edition Leipzig, 1997.

Friedrich, Markus. “'Türken' im Alten Reich: Zur Aufnahme und Konversion von Muslimen im deutschen Sprachraum (16.-18. Jahrhundert).” Historische Zeitschrift 294, no. 2 (2012): 329-360.

Jones, Adam, ed. German Sources for West African History 1559-1669. Wiesbaden: Steiner, 1983. Konrad, Joel. "'Curiously and Most Exquisitely Painted': Body Marking in British Thought and Experience, 1580-1800.” PhD diss., McMaster University, 2011.

Kroll, Frank-Lothar, and Hendrik Thoss, ed. Zwei Staaten, eine Krone: Die Polnisch-Sächsische Union 1697-1763. Berlin: Bebra Wissenschaftsverlag, 2016.

Krutak, Lars F. Tattoo Traditions of Native North America: Ancient and Contemporary Expressions of Identity. Arnhem: LM Publishers, 2014.

Lind, Vera. "Privileged Dependency on the Edge of the Atlantic World: Africans and Germans in the Eighteenth Century." In Interpreting Colonialism, edited by Byron R. Wells, 369-391. Oxford: Voltaire Foundation, 2004.

Navin, John J. The Grim Years: Settling South Carolina, 1670-1720. Columbia: University of South Carolina Press, 2019.

Odle, Marin. Skin Deep: Tattoos, Scalps, and the Contested Language of Bodies in Early America. Philadelphia: University of Pennsylavania Press, forthcoming.

Ramsey, William L. "A Coat for 'Indian Cuffy': Mapping the Boundary between Freedom and Slavery in Colonial South Carolina." The South Carolina Historical Magazine 103, no. 1 (2002): 48-66.

Shoemaker, Nancy. A Strange Likeness: Becoming Red and White in Eighteenth-Century North America. Oxford: Oxford University Press, 2006.

Spohr, Arne. "'Mohr und Trompeter': Blackness and Social Status in Early Modern Germany." Journal of the American Musicological Society 72, no. 3 (2019): 613-663.

Sullivan, John Jeremiah. “The Princes: A Reconstruction.” The Paris Review 200 (Spring 2012): 35-88.

Symcox, Geoffrey, and Giovanna Rabitti. Italian Reports on America, 1493-1522: Letters, Dispatches, and Papal Bulls. Turnhout: Brepols, 2001.

Vaughn, Alden T. Transatlantic Encounters: American Indians in Britain, 1500-1776. New York: Cambridge University Press, 2006.

Wotschke, Theodor. "Oberhofprediger Marperger in Briefen an A.H. Francke." Zeitschrift für Kirchengeschichte Dritte Folge II, 51 (1932): 169-201. 


\section{4 "I Have No Shortage of Moors": Mission, Representation, and the Elusive Semantics of Slavery in Eighteenth-Century Moravian Sources}

In a letter written in apparent haste to request the expeditious transfer of an enslaved young woman named Cecilia, Count Nikolaus Ludwig von Zinzendorf assured the recipient, Danish plantation owner Johan Lorentz Carstens, that his only concern was for the woman's soul. "After all,” he added, "I have no shortage of Moors."1

Committed to paper as a thoughtless aside seemingly bespeaking aristocratic selfconfidence and sense of entitlement, this statement is remarkable. Not only does it attest to the extension of slavery and the slave trade to Northern and Central Europe, it also provides an insight into how Moravians perceived enslaved men and women living among them in Germany, as well as the motivations for bringing them there. What is more, it represents a small breach of the peculiar silence encountered in the sources when researching the presence of enslaved persons in the Moravian communal settlements (Gemeinorte). Typically, Moravian archives remain mute as far as the ambiguous status and slavery background of Africans or West Indian Creoles living in the communities is concerned. On the surface, they appear as brothers and sisters who ideally provided edifying examples of missionary achievement and spiritual awakening. The experience of slavery - shared in different ways by slaves and enslavers - and its confrontation with Moravian life in Europe stay hidden beneath this surface. Therefore, research on non-Europeans in the Gemeinorte is especially concerned with things left unsaid: It has to contend with the lacunae and omissions in the written discourse.

1 Unity Archives Herrnhut (UA), R.15.B.a.1.IV.2.g, Nikolaus Ludwig von Zinzendorf to Johan Lorentz Carstens, March 15, 1741. The case is discussed in more detail below. In the original German, Zinzendorf used the female term Mohrinnen. Indeed, there were four women or girls and one boy from St. Thomas living in Marienborn and Herrnhaag in 1740.

Notes: Publication was made possible by funding from the European Research Council (ERC) under the European Union's Horizon 2020 research and innovation program (grant agreement no. 641110, "The Holy Roman Empire of the German Nation and Its Slaves," 2015-2022). However, this text reflects the author's views exclusively. The ERC is neither responsible for the content nor for its use. The text of this contribution was much improved thanks to the insightful and immensely helpful comments of Rebekka von Mallinckrodt, Sarah Lentz, Annika Bärwald, Julia Holzmann, and Jasper Hagedorn. Special thanks go to Julia Holzmann for kindly sharing her intimate knowledge of Dutch sources and archives. 